\title{
Entrepreneurial Education and Internationalisation of Firms in Transition Economies: A Conceptual Framework from the Case of Croatia
}

\author{
Peer-reviewed version forthcoming in World Review of Entrepreneurship, Management \\ and Sustainable Development
}

\author{
Riccardo Rialti \\ University of Florence, Italy \\ Massimiliano M. Pellegrini \\ University of West London, UK \\ Andrea Caputo \\ University of Lincoln, UK \\ Marina Dabic \\ University of Zagreb, Croatia \\ Nottingham-Trent University, UK
}

\begin{abstract}
The aim of this paper is to offer an integrated perspective on internationalisation process in transition economies and the role that an entrepreneurial education can play in it. The context of a transition economy, such those countries belonging to the former Yugoslavian republic, deeply affect the entrepreneurial activities established. Internationalisation offers a viable advantage to entrepreneurs and their firms to overcome a limited internal market and hostile conditions faced in the local environment. Thanks to the results obtained by a stream of studies focused on the entrepreneurial context in Croatia, we build a framework to explore the problems faced by entrepreneurs when internationalisation is considered and possible solutions. Our main contribution is the proposition of an entrepreneurial education as facilitator of the process. Indeed, entrepreneurial education, considered as formal education and an entrepreneurial university context, can directly ameliorate the process of internationalisation. Simultaneously it can also affect the networking strategy that in literature is another prominent element tackled regarding the problem of internationalisation in transition economies. Thus, entrepreneurial education may represent a strong boost in which to invest with public policies and targeted interventions.

Keywords: Entrepreneurial Education, Entrepreneurship, Internationalisation, Transition Economies, Croatia, Network.
\end{abstract}




\section{Entrepreneurial Education and Internationalisation of Firms in Transition Economies: A Conceptual Framework from the Case of Croatia}

\section{Introduction}

Macro-economics and sociocultural factors are known to be major elements in shaping entrepreneurial activities and the mind-set to approach such problem (Welter, 2011).

Specific to those countries of the former Yugoslavia, hostile conditions for private initiative, planned economy, instability both social and political, civil war and limited size of the domestic market can be listed as some of the factors influencing the entrepreneurial evolution and diffusion (Dana, 1999; 2010; Ramadani, 2013; Ramadani and Dana, 2013; Ramadani, Hisrich \& Gerguri-Rashiti, 2015).

In such conditions, entrepreneurship in transition economies has been exploited to overcome unemployment (Dana, 1997; Hoxha, 2008) and often rely on personal finance or on financing means from families and friends (Hitt et al., 2000; Manolova et al., 2014).

However, despite all these negative conditions, the entrepreneurial context nowadays is flourishing in these countries (Dabić et al., 2012; Dana and Ramadani, 2015). Recently, with the advent of the globalisation era, many firms, even small and medium, have approached the compelling strategy of going international. The process of internationalisation for firms from a transition economy country is possibly different compared to what happens in developed countries. Indeed, internationalisation is almost a "necessary step" in evolutionary growth even in the early stage of the life cycle, and so, it is undertaken much more frequently (Ahlstrom and Bruton, 2010; Manolova et al., 2010; Manolova et al., 2014). On the other hand, these entrepreneurs face serious conditions such as a lack of precise information, the ability to recognise opportunities, and capital (Gorodnichenko and Schnitzer, 2013).

In order to overcome those relevant problems, entrepreneurs from transition economies started to leverage their personal networks (e.g., He, 2009; Musteen et al., 2014a, 2014b; Ramadani et al., 2015). Personal networks and relational strategy help in overcoming and leveraging liabilities related to smallness, foreignness, and capital shortages (Zahra, 2005). Networks, thus, are instrumental in allowing growth of small and medium enterprises in transition economies (Dana et al., 2008).

Considering these facts, it is undeniable that major attention needs to be paid to this phenomenon (Ramadani and Dana, 2013). In order to respond to such a call we proposed an integrated framework built upon studies performed in Croatia.

Croatia is a country where entrepreneurship is a fairly diffused phenomenon; entrepreneurs historically started their ventures during the civil war between 1991 and 1994, and stabilisation of the country only made the growth of the number of enterprises greater (Dana et al., 2012; Ramadani and Dana, 2013).

Our general framework explores in this internationalisation panorama how initiatives of entrepreneurial education can ameliorate the situation. In particular, we followed the guidelines offered by Fayolle (2008) on an effective entrepreneurial training, and we coupled these insights with the emerging studies on entrepreneurial universities, institutions deeply involved in entrepreneurship in a wide sense. We propose that an integrated approach to 
entrepreneurial education can directly influence the chance of success for internationalisation and at the same time favours the networking abilities.

Our contribution is at least twofold. On one hand, we proved a quite unexplored connection between internationalisation and entrepreneurial education. This approach, despite being quite new, is valuable enough to be examined further, since this type of education is very relevant to facing the problems of internationalisation, and specifically those experienced by entrepreneurs from transition economies. Secondly, we show how entrepreneurial education can act both directly in the process, and on the network strategy that is often used to overcome deficiencies in the social and institutional domestic environment. Formal entrepreneurial education and the entrepreneurial university context for students seem to act upon both the process itself (internationalisation) and its facilitator (networking).

Further, one result of this paper is the development of a conceptual framework, illustrating the mediating role of entrepreneurial education and of entrepreneurial universities in stimulating the birth of new entrepreneurial firms and in facilitating internalisation of established firms in transition economies (e.g., Aaltio, 2008; Alon and McIntyre, 2008; Domadenik and Pastore, 2006; Varblane and Mets, 2010). These economies, in particular Croatia, have been deemed as the ideal field of investigation (e.g., Sohinger and Horvatin, 2005). In these economies, in fact, the birth, growth and internalisation processes of firms are heavily influenced by the context.

This paper is structured in the following manner. Apart from this introduction, in the next section we present a literature review about entrepreneurship and internationalisation, specifically that occurring in transition economies. In the third part, the possible role of entrepreneurial education and entrepreneurial universities as facilitators of the internalisation of firms is explored, with a specific focus on transition economies' current status quo. In the fourth section, we draw specific insights from the Croatia country-case. Thanks to this, in the fifth part, we develop a conceptual framework with propositions to interpret in a coherent manner the empirical evidence collected from the country-case study, and to present an exemplary model that can be used as a benchmark for other similar economies in transition. The framework clearly highlights how an integrated approach to entrepreneurial education can facilitate the internationalisation process. Finally, we briefly summarise implications, limitations and the value of this paper for future research..

\section{Entrepreneurship and internationalisation in transition economies}

Entrepreneurship has historically been one of the most widely investigated topics in economic literature (Shane and Venkataraman, 2000). Traditionally related with the creation and growth of economic activities (Davidsson, 1991; Lee et al., 2004; Wright and Stigliani, 2013), entrepreneurship has been studied with multiple facets over the past years. It has been identified as one of the main elements of economic growth and GDP increases (Wong et al., 2005); as a factor fostering the economical sustainability of developing countries (Ahmed and Mcquay; 2005); as a factor influencing regional development through jobs creation (Venkataraman, 2004; Fayolle, 2007; Baptista et al., 2008); as one of individual responses to unemployment (Caputo, Lombardi et al., 2016; Gohmann, 2012; Hoxha, 2008; Tipu, 2012) 
in times of economic recession (Fairlie, 2013); as a driver of innovation and new product creation (Audretsch and Link, 2012; Drucker, 2014; Joshi, 2010); as a means of female and youth empowerment in developing contexts (Caputo, et al., 2016; Ramadani et al., 2015). Thus, successful entrepreneurship has historically been addressed as a social phenomenon characterised as a social function for the development of communities (Wilton and Toh, 2012).

Key to such studies has been the philosophical speculation on the meaning of the word entrepreneur. Knight (1921), following a well consolidated stream of literature that begins with Richard Cantillon's (1755) theories, recognised the entrepreneur as someone that is willing to bear economic risk in order to commercialise a new idea. Schumpeter defined an entrepreneur as a person who is able to convert an idea into a successful innovation, creating a value (1942). While Marshall and Guillebaud (1961), similarly, identified the entrepreneur as a capitalist able to innovate and create new products. However, in spite of this constant interest overtime of literature, some topics about entrepreneurship have started to be explored by scholars only in more recent times (Dana, Dana and Spence, 2004; Dana, Han, Ratten and Welpe, 2012; Wright and Dana, 2003; Young, Dimitratos and Dana, 2003). Among these topics it is possible to include entrepreneurship and internationalisation of entrepreneurial firms in transition economies (Dana, 1997, 1998, 1999, 2010; Dana and Ramadani, 2015; Pollard and Simberova, 2008; Ramadani, 2013; Ramadani and Dana, 2013; Ramadani et al., 2015).

\subsection{Entrepreneurship in transition economies as a field of study}

The expression transition economy in economic literature is used to describe countries whose economic system has shifted, or is shifting, from being centralised and government controlled to a market economy (e.g. Dana and Ramadani, 2015; Gurau and Dana, 2010; Smallbone and Welter, 2006). Thus, transition economies are countries that are progressively opening their markets towards the global economy. Furthermore, in these economies economic growth is related to increasing contact with other economies (Dana et al., 2012). Due to peculiarities of those economies, in recent time literature is dedicating an evergrowing attention toward the situation of entrepreneurship and small businesses operating in the economies of former communist regimes (Dana, 1999). In particular, in a first historical phase the evolution of entrepreneurship and the birth of SMEs have been explored in China and Vietnam (Dandridge and Flynn, 1988; Chau, 1995). Then, authors moved their attention towards former soviet countries like Kazakhstan, Czech Republic, Poland and Baltic Countries (Hisrich and Gratchev, 1993; Dana, 1997; Klonowski, 2008; Zapalska, 1997). Finally, mostly due to the more recent Yugoslavian dissolution, attention started to move in the late nineties towards the Balkans. The aim of the majority of these studies was demonstrating that context is one of the principal factors influencing and modifying the motivations behind becoming an entrepreneur. Such studies outlined how entrepreneurs in transition economies are different from their developed countries counterparts. In the next sections, we will further explore such concepts (e.g., Gurau and Dana, 2010; Smallbone and Welter, 2006). 

paradigm

Entrepreneurship diffusion and personal attitudes toward becoming an entrepreneur are heavily influenced by macro-economic factors and social-cultural factors (Dana el al., 2012).

In developed western countries, characterised by business friendly environments and political stability since the Second World War, entrepreneurship have thrived and many have become entrepreneurs in order to capitalise on innovation and on existing market niches. For other countries however, such as those of the ex-soviet bloc or of the ex-Yugoslavian peninsula, the same cannot be said (e.g., Birzulis, 2002; Gurau and Dana, 2010). Problematic environments, a combination of political and economic instability, lack of effective policies supporting entrepreneurs, limited sizes of domestic demand and market, and conflicts have substantially altered motivational and intentional models to pursue such a career, and to some extent the concept of "being an entrepreneur" in these countries (Aidis, 2005; Dana, 1997, 1998, 1999, 2010; Dana and Ramadani, 2015; Ramadani, 2013; Ramadani and Dana, 2013; Smallbone and Welter, 2006).

Traditional literature focused on entrepreneurship in transition economies, paid much attention to the role of privatisation and liberalisation during peacetime. This element indeed has allowed private entrepreneurship to flourish, or in some cases even become legal (Dana et al., 2012). Nevertheless, although these two processes are prerequisites, the phenomenon of becoming an entrepreneur or starting a company is much more complex than simply the statutory right for private citizens to engage with economic activities.

Accordingly, the academic debate has recently also moved forward, beyond the mere role of privatisation and liberalisation that remain elements studied for entrepreneurial diffusion (Dana, 1997; Dana et al., 2004; Estrin et al., 2009; Dana et al., 2012; Ramadani and Dana, 2013). The expansion of the phenomenon of entrepreneurship in transition economies hence is related to the evolution of the context in time and it is influenced by several factors: the legacy of the communist period that created a hostile environment for private business, a series of new social needs, the tormented conflicts, and the instability of a relatively young and not well-balanced market (Hitt, Dacin, Levitas, Arregle and Borza, 2000; Wright and Dana, 2003). Firstly, "entrepreneurs" operating in a parallel, mostly illegal or informal, economy appeared (e.g. Williams, 2015). Secondly, "regular entrepreneurs" started doing business after wars. In particular, when and where economy was growing again (Julien, 1989).

During communist regime, the economy of transition economies was strictly regulated; central planning in effect did not left much space for private initiative (Hitt et al., 2000). Private initiative in fact was forbidden by law in the majority of communist regimes (Smallbone and Welter 2001; 2006). In this situation, the allocation of resources and goods was utterly inefficient, and a black market, for foreign goods in particular, was thriving. Thus, doing business in parallel with the regulated economy became the first form of "entrepreneurship" in those countries. Private citizens, due to these inefficiencies, then started becoming "entrepreneurs" in the parallel economy, providing solutions to inefficiencies and gaining profits from that (Grossman, 1977; Lavigne, 1995). Such economic activities, mostly related to smuggling, continued to grow during the war and during the first 
phases of transition, making the fortunes of many (Dana, 1998; Ramadani and Dana, 2013). Furthermore, this fact has contributed to shaping the post war economy in many transition economies with a high level of distrust toward institutions (Johnson et al., 1997; Feige and Ott, 1998; Johnson et al., 2000; Smallbone and Welter, 2006).

After the conflict, or eventually after the fall of a regime, frequently a phase of progressive normalisation of the situation began (Tridico, 2013). In this period, privatisation, liberalisationand economic development played a crucial role in the birth of the new business and in diffusion of entrepreneurship. Firstly, privatisation of national conglomerate caused increases in unemployment to a problematic level (Commander and Coricelli, 1995; Hoxha, 2008). Thus, many unemployed, as often happens during recessions or after the collapse of firms (Shepherd, 2003), began to create small businesses in order to work again as selfemployed (Meager, 1992; Ramadani and Dana, 2013). Then, becoming an entrepreneur in the first phase of transition towards a market economy was effectively necessity driven (Ageev et al., 1995; Tipu, 2012). Secondly, liberalisation and a market economy pushed the now privatised firms to achieve profitability and survive in an open market, to vacate many market niches, which were progressively served by new private entrepreneurs (Ramadani and Dana, 2013; Petković and Tešić, 2013).

In such conditions, entrepreneurship in transition economies flourished, often to overcome market inefficiencies and as a response to unemployment. Those entrepreneurs therefore rarely are Schumpeterian innovators (1942) in the traditional sense; frequently their businesses operate in traditional sectors of economy like agriculture, construction, manufacturing and distribution (Peng, 2001; Ramadani and Dana, 2013; Ramadani, 2013; Ramadani, 2015). Furthermore, in order to establish a new entrepreneurial venture, those entrepreneurs often rely on personal finance or on financing means from families and friends, principally because in transition economies a well-structured financial system does not yet exist (Hitt et al., 2000; Manolova et al., 2014).

Those entrepreneurs often do not possess a traditional academic education (e.g., Aaltio, 2008; Alon and McIntyre, 2008 Domadenik and Pastore, 2006; Varblane and Mets, 2010). Principally, many new entrepreneurs in fact are former farmers that received lands formerly expropriated by the government, former communist party executive exploiting their political knowledge to start businesses, former enterprises' workers now unemployed and former operators in grey market (Ageev et al., 1995; Peng, 2001:96). In addition, many innovative new ventures are indeed established by former migrants returning home after a period of work in a foreign country, during which they have acquired some knowledge on business administration and management (Ramadani and Dana, 2013). Apart from former unemployed people starting their own ventures, the principal motivation behind becoming an entrepreneur in transition economies is the desire for professional independence, the necessity to boost income and for personal fulfilment (Peng, 2001; Smallbone and Welter, 2001). In contrast to developed countries middle-aged entrepreneurs and entrepreneurs leading micro enterprises from transition economies show a high aversion to risk taking and prefer to operate in classical sectors of economies instead of differentiating or innovating (Smallbone and Welter, 2001).

Due to the particular context of origin of those firms, and of the peculiarities of those entrepreneurship venture like difficult financing, sector of operation and lack of 
innovativeness, for those firms it is difficult to compete on an international level and to internationalise their business (e.g., Pollard and Simberova, 2008).

\subsection{Internationalisation in transition economies}

Internationalisation has been defined as the process of expansion towards a different country market from the one where the firm has been established (Calof and Beamish, 1995). Internationalisation occurs in several forms; firms that have some relations with a foreign counterpart or that have some of their activities in a foreign country can be classified as internationalised, to some extent (Gurau, 2002; Kalinc and Forza, 2012; Pollard and Simberova, 2008). Many motivations may justify the decision to undertake a strategy of internationalisation: a cost-cutting strategy moving less value activities towards country with lower labour cost (Wolf, 1977; Lee and Makhija, 2009); fiscal benefits transferring part of the firm in a country with a lower taxation system (Swank, 2006); exploiting competitive advantages established in the home country in less developed countries (Westhead et al., 2001); a strategic response to a competitor which is internationalising or already internationalised (Zucchella et al., 2007); expanding business towards a new market in pursuing new market opportunities or after reductions in the internal demand (Kyläheiko et al., 2011; Hessels and Parker, 2013).

In the last decades, the progressive phenomenon of the "global economy" has appealed many firms from developed countries toward international market (Dana et al., 2012), and this is mostly due to business friendly environments and positive policies toward the international expansion of businesses (Dana, 2001). However, firms from transition economies did not follow such a trend; internationalisation for them is still a recent phenomenon even in the academic literature (Dana, 1997, 1998, 1999, 2010; Dana \& Ramadani, 2015; Pollard and Simberova, 2008; Ramadani, 2013; Ramadani \& Dana, 2013).

The process of internationalisation of enterprises from transition economies is a phenomenon with specific characteristics compared to those firms in developed countries. First, internationalisation in transition economies is mostly seen as a "necessary step" in evolutionary growth (Ahlstrom and Bruton, 2010; Pollard and Simberova, 2008) and may occur in the first phases of firms' life cycle, contrary to the traditional pattern of their western counterparts (Manolova et al., 2014). Second, firms from transition countries try to undertake processes of internationalisation more frequently than the ones from developed countries (Manolova et al., 2010). Indeed, the business models of those firms are focused on creating value by exporting products produced at minor cost due to lower cost of labour (Manolova et al., 2010). The principal motivations of these differences with respect to firms from developed countries thus are related to a smaller domestic markets of their countries of origins and lower manufacturing costs that allow them to export the majority of their products (Hitt et al., 2000).

Such considerations are valid even when talking about SMEs and entrepreneurs of these countries who wish to internationalise. In developed countries, studies have indeed identified that one of the principal problems faced by entrepreneurs in internationalisation processes is the choice concerning the entry strategy, i.e. the best strategy to approach the new market (Andersen, 1997). Instead, in transition economies scholars observed that the main problems 
experienced by entrepreneurs are: a lack of precise information about the target market (Greenaway et al., 2007), a lack of financial resources to be invested in internationalisation in combination with an impossibility of raising capital from the domestic financial market (Gorodnichenko and Schnitzer, 2013).

In order to overcome those three relevant problems deriving from the institutional context, entrepreneurs from transition economies started to leverage their personal networks (He, 2009; Musteen et al., 2014a, 2014b). Leveraging personal networks appears as principal solution to institutional problem of transition economy, and thus the most interesting characteristic of the internationalisation in these economic systems. Networks help in overcoming and leveraging liabilities related to smallness, foreignness, and capital shortages (Zahra, 2005). On one hand, personal networks can assist in opportunity recognition (He, 2009), facilitating the development of international marketing strategy (Coviello, 2006; Tang, 2011), and increasing the quantity and the quality of knowledge resources needed to compete (Aldrich and Carter, 2004; Patton, 2014). Thus, they play an effective role in speeding up the process (Kiss and Danis, 2010). On the other hand, personal networks may also allow entrepreneurs to raise the capital necessary at the beginning of the internationalisation process or to absorb potential losses. Such "sources" of capital, in most cases, are noninstitutional such as friends, family members or other partners (Musteen et al., 2014a).

Thus, in transition economies, the role of financial institutions, that principally is limited to allocating some international subsidies for business, is only marginal and often completely replaced by private national or international networks (Musteen et al., 2014b). For this reason, institutions should seriously reflect upon what kind of support, programs, and ad hoc policies offered to entrepreneurs and firms that are willing to internationalise. Some examples could be: implementing easier systems to access public funding; activating training courses on international trading and legal systems; encouraging formal courses focused on management, business administration and entrepreneurship (Manolova et al., 2014).

A summary of these considerations is visually reported in figure 1

\section{Figure 1 about here}

Exactly in line with the last consideration, the third paragraph explores the role of entrepreneurship education as a facilitator for internationalisation of SMEs.

\section{Entrepreneurial education as a key facilitator for internationalisation}

A traditional approach to entrepreneurship implies that only some people with natural predispositions could eventually become entrepreneurs during their life (Cunningham and Lischeron, 1991), thus such a discipline cannot be taught (Thompson, 2004). However, more recently this concept is rapidly losing consensus; in fact, an ever-growing number of authors agree with Drucker's (1958) idea that some aspects of entrepreneurship can be effectively taught or at least trained (Kuratko, 2005). As proof of such achange in mind-sets, in recent years many universities all over the world have started offering a growing number of entrepreneurship-related academic programs (Fayolle, 2013); in the U.S. alone, more than two thousand courses have been activated (Kuratko, 2005). 
Even in this favourable context toward entrepreneurial education, a standard method of how to teach entrepreneurship to students still does not exist in literature (Fayolle, 2008). Entrepreneurial programs are frequently driven by more educators' experiences than scientific theories (Fayolle, 2008). Anyways, as entrepreneurial education became a more mature field of research, a prevalent model has appeared. This model, which descends directly from traditional education science (Green and Rice, 2007; Fayolle, 2008), is based on five questions educators must answer to be effective: Why it is necessary to teach entrepreneurship? What should be thought in terms of the content? Who is composing the audience? How could some facts of entrepreneurship be transmitted to them? What are the expected results?

Following this model, the educator or the institution first has to identify which social needs $\mathrm{s} /$ he is answering, and has to focus on which goals entrepreneurial education program should achieve (Fayolle, 2008). According to Kirby (2007), making the student understand the entrepreneur's role in the society and the appeal of this career is one of the most important goals. Secondly, there is the design task i.e. selecting and organising contents of the program that can balance the two "souls" of the discipline (Fayolle and Gailly, 2008). The educator has to simultaneously transfer knowledge of the "professional" dimension of entrepreneurship (hard skills), which consists of know-what, know-how and know-who, and of the "spiritual" dimension (soft skills), which is the know-why and know-when of acting, with a flavour of theories on entrepreneurship (Fayolle, 2008). Thirdly and fourthly, then, the educator should focus on the task of identifying the level of competence of the audience, and then select the methods of teaching and delivery. Fifthly, and finally, educators' focus on structuring an entrepreneurial education program has to determine methods for assessment of results (Fayolle, 2008; Fayolle and Gailly, 2008).

Entrepreneurial education programs, if well structured and organised following a validated framework, can potentially stimulate entrepreneurial latent propensity in students and can prepare them to entrepreneurship in real world (e.g., Aaltio, 2008; Varblane and Mets, 2010). Furthermore, ad hoc entrepreneurship education programs can also be instrumental in modifying the propensity of students and existing entrepreneurs toward internationalisation, particularly in contexts such as transition economies (Dabic et al., 2012). For example, a program focused on a particular know-who could provide students useful insights that can help them in the process of internationalisation and in the formation of new networks (Aaltio, 2008; Johannisson, 1991). A program focused on know-when could be instrumental in preparing new entrepreneurs in taking decisions on when to change a strategy (Fayolle, 2008). Finally, a program with a great quantity of information on financial structures can be instrumental in teaching students how to build a balanced capital structure and how to raise capital for internationalisation (Johannisson, 1991).

Thus, education can theoretically be a facilitator of internationalisation. Specific programs aiming at teaching how to internationalise a firm furthermore can thus also be activated in their home country.

\subsection{The state of entrepreneurship education programs in transition economies}


After the fall of communism, principally due to an increasing awareness on the role of entrepreneurship for economic development, some entrepreneurship education specific programs have been promoted by governmental institutions. However, the quality of these first attempts was quite low. Indeed, although education has always been a priority in many of those countries even during communism, the education programs in entrepreneurship were based primarily on transferring knowledge on hard skills like chemistry and mechanics, and changing the mind-set of educators was almost impossible (Aaltio, 2008; Ibicioglu et al., 2008; Varblane and Mets, 2010). Due to a greater need for entrepreneurial formation, as well as the new availability of foreign educated professional teachers and scholars (Matlay, 2001), the situation of entrepreneurship education in transition economies is rapidly changing (Varblane and Mets, 2010). In recent times, collaboration with universities from fully developed countries has had principal effects on the establishment of courses on the topic. The focuses are related to the stimulation of personal vocation toward becoming an entrepreneur, and naturally the development of entrepreneurial ideas, and academic programs on SMEs management (Jones et al., 2008; Varblane and Mets, 2010). The role of education furthermore has become even greater after an increased legitimacy in the literature and in practice of the concept of the "triple helix", a paradigm in which university, industry, and government are necessary actors for rapid economic growth and innovation (Etzkowitz and Leydesdorff, 2000).

In spite of these huge changes in the education sector in transition economies, some problems persist. For instance, entrepreneurship programs are still limited; most of the time they are quite traditional management courses with few modules focused on entrepreneurship and an even smaller number aiming at developing entrepreneurial attitudes, vocation, and soft skills and mind-set (Jones et al., 2008). There is also a need for modules led by practitioners, i.e. "real life" entrepreneurs, due to their role model function and thus a more incisive involvement in teaching activities. Regarding the pedagogical aspects, teaching rarely is in English and there is still a too passive approach to learning (Verblane and Mets, 2010).

An effort should be made to remove such problems since students and entrepreneurs have shown positive responses towards attending vocation-oriented courses (Matlay, 2001). New academic programs on entrepreneurship specifically designed for a transitional economy environment should have a series of requisites. Regarding the "professional" dimension of entrepreneurship (Fayolle and Gailly, 2008) the programs should consider how to finance a firm, how to improve human relationships, how to plan a strategy and the creation of a business plan (Ibicioglu et al., 2008; Jones et al., 2008). Concerning the "spiritual" dimension (Fayolle and Gailly, 2008) new programs should contribute to making new and potential entrepreneurs proactive towards problems and decision-making and more favourable toward innovation (Lloyd-Reason et al., 2002).

The implementation of policies to develop entrepreneurship education programs in transition economies can thus have a huge potential impact on economic development of those countries; especially if governments and universities will encourage and support the creation of on entrepreneurship programs where students have strong interaction with entrepreneurs and potential investors (Arthur et al., 2012). However, teaching students and entrepreneurs how to internationalise their venture firm will be fundamental in the future to 
avoid the classical problem of a transitional economy, i.e. the relative small market and a lack of internal demand (Dana, 2001).

\section{Context of research: Evidence from Croatia}

Croatia is a country of 21,829 square kilometres in Eastern Europe. It borders with Bosnia-Herzegovina, Hungary, Montenegro, Serbia and Slovenia. Furthermore, Croatia also has a mainland coastline on Adriatic Sea, approximately 1,777 kilometres long. In 1991, in the same moment as Slovenia, Croatia became the first country of former Yugoslavia to declare its independence. This then caused a civil war that lasted until 1995. In the last phases of the civil war (1994), to prepare to be an independent country, Croatia started the transition from a planned economic system towards a market economy, privatising some of the national enterprises. This process, albeit often being defined as a "tycoon based privatisation" (Glas et $a l ., 2000$ ), was relevant and represented the first step toward becoming a modern economy.

However, Croatia, while being one of the first countries in the Balkans to privatise public firms, was less reactive in implementing policies to favour entrepreneurship development, which was activated only some years later. In 1997, the state granted a concession for a free economic zone in Osijek and then in 2001, the Strategic Planning Office of the Government recognised entrepreneurship and technological activities as top priorities to be incentivised (Dana et al., 2012; Sohinger and Horvatin, 2005). They also removed the existing barriers for foreign investments. Finally, in 2002, the first law promoting entrepreneurship was ratified.

As of 2010, the effects of these progressive policies are evident: Croatia nowadays counts more than 90,000 enterprises (Dana et al., 2012; Ramadani and Dana, 2013). According to the FINA data set (Dabic et al. 2013), the ex-public Financial Agency for bookkeeping services, in the new millennia before the worldwide economic crisis around 9,000-10,000 new enterprises have been established in Croatia every year, especially in Adriatic Croatia where, between 2001 and 2007, there was an increase of $44.37 \%$ of newly opened firms. Despite this fact, the densest region of Croatia in terms of firms is North-West Croatia, a region that counts 23.8 enterprises for every 1000 inhabitants. The Adriatic region ranks second, counting 22.8 enterprises for every 1000 inhabitants, and the Eastern region (Pannonia) is the one with the lowest number of enterprises, only 8.5 for every 1000 inhabitants. Zagreb city, the capital, counts a concentration of 35.3 enterprises for every 1000 inhabitants. Enterprises, furthermore, employ a significant part of population in Croatia: around $55 \%$ of men and circa $45 \%$ of women (Ramadani et al., 2015).

Thus, Croatia is a country where entrepreneurship is a fairly diffused phenomenon. Entrepreneurs historically started their ventures during the civil war between 1991 and 1994 and stabilisation of the country only made the growth of the number of enterprises greater (Dana et al., 2012; Ramadani and Dana, 2013; Sohinger and Horvatin, 2005). While the significant risks posed by internal political stability are no longer of a concern, entrepreneurs in Croatia still struggle with lack of financing, a heavily reliance on export and risks related to variability in legal environment as the most relevant threats to their regular operations (Bublic et al., 2013). In particular, as also found in other transition economies (Iakovleva and Solesvik; 2014), lack of knowledge on how to finance a start-up firm has been identified as 
one of most relevant problems hampering the growth of a new entrepreneurial venture (Dabic et al., 2012; Ramadani et al., 2015).

Such a huge phenomenon of entrepreneurship seems to be tied to a well-developed entrepreneurial spirit and propensity of young generations, and many studies have been focused on this. The study of Dabic et al. (2013) showed how Croatian students in economics and management usually are more prone to start their own venture in comparison with students from other former transition economies. Even in terms of desirability of becoming an entrepreneur, results from a study on the University of Zagreb performed by Dabic et al. (2012) show how students would be enthusiastic in starting their own venture and how they feel to have support from their families. Similarly, Croatian students believe that they are more prepared than their counterparts from other countries (Dabic et al., 2012). Contrarily, they also believe that managing a business may be overwhelming, and starting a business in a former transition economy can be riskier due to problems related to financing and later to a successive internationalisation process (Dabić et al., 2012). For the gender issue, differences in the propensity toward entrepreneurship between male and female still persist; male are still more positive about entrepreneurship, although this difference is decreasing in the last years (Dabic et al., 2012); a matter that has also been found in other contexts (e.g. Caputo et al., 2016; Ramadani et al., 2015).

Due to the flourishing of entrepreneurial activities and the entrepreneurial mind-set of the young generation coupled with the difficulties encountered, Croatia represents an ideal context of analysis to develop a framework that can be adopted by other Balkan realities and in general for transition economies.

\section{A framework on the role of entrepreneurial education and entrepreneurial university in transition economy.}

As assessed by the literature on internationalisation in transition economies, the principal facilitator for SMEs and entrepreneurs oriented toward internationalisation are personal networks (Dana, 1997, 1998, 1999, 2010; Dana \& Ramadani, 2015; Ramadani, 2013; Ramadani \& Dana, 2013). However, despite apparent efficacy of this expedient, networks alone cannot be sufficient in ensuring open access to internationalisation processes. Firstly, business partners do not fully trust younger and smaller firms, thus such firms cannot raise capital from suppliers (Manolova et al., 2010). Secondly, information on potential market and legal environment is frequently obtained from networks that are based on personal experience rather than from verified sources, hence often some information lack of some key particulars (Musteen et al., 2010). Thirdly, some firms are not part of existing transnational networks and internationalisation can be almost impossible (Musteen et al., 2010; Musteen et al., 2014).

Furthermore, another obstacle in starting the process of internationalisation for an SME can be identified in the fact that entrepreneurs lack theoretical information about entrepreneurship, internationalisation and ways of financing (Manolova et al., 2010; Manolova et al., 2014).

In order to overcome all these problems in a network-based approach to internationalisation (figure 1), the next paragraph is dedicated to demonstrating how 
entrepreneurial education can be one of the elements to ameliorate the situation of entrepreneurs from transition economies when approaching the internationalisation issue (figure 2).

\subsection{Entrepreneurial education and the internationalisation phenomenon.}

The function of entrepreneurial education in stimulating personal propensity toward becoming an entrepreneur has widely been analysed in literature (Dabic et al., 2012; Van Der Kuip and Verhuel, 2004; Marques and Albuquerque, 2012). Furthermore, the role of entrepreneurial education in providing a fundamental theoretical background to manage an enterprise in a successful way has also been discussed (Elmuti et al., 2012). Nevertheless, in a context characterised by a flourishing of studies, the topic of how a specifically formulated entrepreneurship education program can influence the success of an internationalisation process has scarcely been explored (Laukkanen et al., 2000; Lee, 2008). Indeed, Ramadani and Dana (2013) stressed how some universities, in particular in transition economies and in Croatia, should focus more on entrepreneurship and less on business corporations. Despite this scarcity, what we propose is that guidelines for an effective entrepreneurial program can work as well for what concerns internationalisation.

In particular, as we said, a program based on both the "professional" aspect of entrepreneurship (hard skills) and on "spiritual" aspect (soft skills) can be useful for entrepreneurs wishing to internationalise (Fayolle, 2008; Fayolle and Gailly, 2008; Fayolle, 2013). Concerning the professional aspect, an entrepreneurial program can provide precious information about implementing a successful internationalisation process (Fayolle, 2008). The program can teach students how other firms from a similar context realised internationalisation, and/or present how to finance a firm, and/or offer knowledge about normative contexts (Fayolle, 2008; Fayolle and Gailly, 2008). In addition, focusing on the professional aspect, entrepreneurial education programs could provide some important information about networking, the who dimension (Fayolle, 2008), and so provide a platform for stakeholders to implement a successful strategy of internationalisation. For the spiritual dimension of entrepreneurship, an entrepreneurial education program can stimulate reflective thinking from the students to help them wisely evaluate the situation (Fayolle, 2008; Fayolle and Gailly, 2008), helping them in selecting a proper strategy for the contingencies, i.e. why and when to implement a strategy of internationalisation.

Hence, building on this theoretical background, we propose that an entrepreneurial education program focused on both dimensions of entrepreneurship, i.e. "professional" and "spiritual", can improve the chances of success in an internationalisation process.

Pla: The focus on the "professional" dimension confers concrete knowledge on how to navigate an internationalisation process

P1b: The focus on the "professional" dimension confers concrete knowledge on how to network during an internationalisation process and the key stakeholders be partners with

P2: The focus on the "spiritual" dimension confers mental mind-set to evaluate the internationalisation process.

\subsection{Entrepreneurial universities and the internationalisation phenomenon.}


A final aspect that we want to tackle regarding entrepreneurship and internationalisation in a transition economy is integrated with a formal entrepreneurial education, but its focus is more on the institution itself. This is the concept of "entrepreneurial universities" that is also a nascent field in the literature (Slaughter and Leslie, 1997; Etzkowitz, 2004). We only briefly reviewed some of the major research avenues on this topic, but we consider it extremely important to start rising this concern also for contexts belonging to the transitional economies. A universal definition of entrepreneurial university still does not exist, but one of the most used identifies an entrepreneurial university as any academic institution with several characteristics. Its main purpose to stimulate the birth of new businesses (Chrisman et al., 1995) is characterised by a prevalent activity of teaching enterprise development (Etzkowitz, 2000) and that it is directly involved in collaboration with existing enterprises in order to stimulate regional development (Sporn, 2001). In particular, entrepreneurial universities can have a crucial role in increasing their intention and vocation in becoming entrepreneurs (Blenker et al., 2008) and, furthermore, it can be instrumental in helping students start their own venture, allowing them to start their enterprise as a university spin-off (De Cleyn and Braet; 2009; Berggeren, 2011).

Despite being a concept in continuous evolution, an entrepreneurial university context providing entrepreneurial education can have an instrumental role in providing young entrepreneurs the necessary knowledge to implement internationalisation successfully (Pfeifer et al., 2014). First of all, entrepreneurial universities can stimulate contacts between young entrepreneurs, managers and entrepreneurs that have already driven internationalisation processes, thus stimulating direct knowledge transfer between entrepreneurs (Dabic et al., 2015). Secondly, since an entrepreneurial university is usually many potential capital providers and investors, as well as with other firms (Gaff et al., 2012), it could help young entrepreneurs in creating a transnational network usable to implement a semi-classical process of internationalisation. Thirdly, an entrepreneurial university can potentially reduce the distance between enterprises and government (Dutt et al., 2015).

Furthermore, the creation of an entrepreneurial university can be considered a direct intervention from institutions aiming at stimulating entrepreneurship.

Hence, from $t$ the role of entrepreneurial university, we propose the following:

P3: An entrepreneurial university context can facilitate an internationalisation process providing a network of key stakeholders, institutions and business partners to their students.

P4: An entrepreneurial university context can facilitate an internationalisation process allowing transfers of fresh knowledge based on concrete experience to their students.

Our general framework on formal entrepreneurial education and entrepreneurial university context can be summarised in figure 2. Thus, what we are proposing is that an integrated approach to entrepreneurial education can influence directly the chance of success and internationalisation, and at the same time favour the networking abilities and the building phase of an international network. In other words, it seems possible to affirm that entrepreneurial education has an "accelerator" effect acting upon the process itself (internationalisation) and its facilitator (networking). 
Figure 2 about here

\section{Conclusions}

This paper developed a conceptual framework that illustrates how an integrated form of entrepreneurial education, namely formal education and entrepreneurial universities, can be considered to have a mediating role in stimulating the birth of new entrepreneurial firms and in facilitating internalisation of established SMEs in transition economies. Transition economies are a particularly good context of analysis when it comes to entrepreneurship and internationalisation. Indeed, in such economies entrepreneurship left the informal and, sometimes illegal, arena of the pre-transition era and flourished thanks to the opening of such economies, which transitioned from socialism to capitalism (e.g., Ratten, 2014; Williams, 2011, 2015).

In developing our conceptual model, we first reviewed the literature about entrepreneurship, and particularly we focused on the peculiarities of entrepreneurs and entrepreneurial firms in transition economies. Here we reviewed the motives and factors fostering or hindering entrepreneurship and draw a portrait of the context conditions and how the interplay with reference to entrepreneurship. Second, we reviewed the literature on internationalisation of SMEs and entrepreneurial ventures and connected those studies with the peculiarities of transition economies. The internationalisation process is particularly important since it seems to be a necessary step for the development and growth of SMEs in these economies (Dana, 2001; Manolova et al., 2010; Musteen et al., 2014a). Next, we drew our attention on the entrepreneurial education literature, presenting a case study based on empirical evidence collected from Croatia. Finally, we integrated all those bodies of literature in a coherent conceptual framework based on five propositions. Through our framework, future scholars, researchers, entrepreneurs and students can read and understand the role of entrepreneurial education, both formal programs and the institutional approach (i.e. the entrepreneurial university concept), in entrepreneurship in transition economies. At the same time, those interested in studying transition economies or in developing policies in such contexts can benefit from the application of our framework to different contexts.

Entrepreneurial education can be instrumental in helping younger entrepreneurs in internationalising their firms; first for their better approach to the process, second for their enhanced ability for networking. Furthermore, internationalisation can also have other beneficial effects in the original home economy as spill overs in the local system boost a general increase in regional development (Laukkanen, 2000; Baptista et al., 2008).

This paper is intended as an exploratory investigation of the matter, and no quantitative analysis has been realised. Future research could build on our stream of research by populating our framework with actual data. Moreover, the framework could be applied in different countries and a longitudinal study might be undertaken.

\section{References}

Aaltio, I. (2008). Management education as an identity construction: the case of Estonia and its transition economy background. International Journal of Entrepreneurship and Small Business, 5(1), 83-99. 
Ageev, A. I., Gratchev, M. V., \& Hisrich, R. D. (1995). Entrepreneurship in the Soviet Union and post-socialist Russia. Small Business Economics, 7(5), 365-376.

Ahlstrom, D., \& Bruton, G. D. (2010). Rapid institutional shifts and the co-evolution of entrepreneurial firms in transition economies. Entrepreneurship Theory and Practice, 34(3), 531-554.

Ahmed, A., \& McQuaid, R. W. (2005). Entrepreneurship, management, and sustainable development. World Review of Entrepreneurship, Management and Sustainable Development, 1(1), 6-30.

Aidis, R. (2005). Institutional barriers to small-and medium-sized enterprise operations in transition countries. Small business economics, 25(4), 305-317.

Aldrich, H. E., \& Carter, N. M. (2004). Social networks (pp.324-335). In: Gartner W. B. (eds), Handbook of Entrepreneurial Dynamics: The Process of Business Creation. Thousand Oaks, CA: Sage.

Alon, I., \& McIntyre, J. R. (2008). Business education in emerging economies. International Journal of Business and Globalisation, 2(1), 5-27.

Arthur, S. J., Hisrich, R. D., \& Cabrera, Á. (2012). The importance of education in the entrepreneurial process: a world view. Journal of Small Business and Enterprise Development, 19(3), 500-514.

Audretsch, D. B., \& Link, A. N. (2012). Entrepreneurship and innovation. Journal of Technology Transfer, 37(1), 1-17.

Baptista, R., Escária, V., \& Madruga, P. (2008). Entrepreneurship, regional development and job creation: the case of Portugal. Small Business Economics, 30(1), 49-58.

Berggren, E. (2011). The entrepreneurial university's influence on commercialisation of academic research-the illustrative case of Chalmers University of Technology. International Journal of Entrepreneurship and Small Business, 12(4), 429-444.

Birzulis, P. (2002) Go directly to sleaze, do not pass morality. Baltic Times, 7(300), 20, 28 March.

Białek-Jaworska, A., \& Gabryelczyk, R. (2015). Stimulating entrepreneurship by teaching accounting: concept and implementation. World Review of Entrepreneurship, Management and Sustainable Development, 11(2-3), 137-155.

Blenker, P., Dreisler, P., Færgemann, H. M., \& Kjeldsen, J. (2008). A framework for developing entrepreneurship education in a university context. International Journal of Entrepreneurship and Small Business, 5(1), 45-63.

Bublić, V., Hunjak, T., \& Supek, M. V. (2013). Risk management in SMEs: The Croatian experiences. In Ramadani, V. \& Schneider, R. C. (2013). Entrepreneurship in the Balkans (pp. 57-75). Berlin: Springer.

Calof, J. L., \& Beamish, P. W. (1995). Adapting to foreign markets: Explaining internationalisation. International business review, 4(2), 115-131.

Cantillon, R. (1755). Essay on the Nature of Trade in General. Eng. trans. by H. Higgs, New York: AM Kelley.

Caputo, A., Lombardi, R., Akeel, F., Almallah, H., Dakkak, B. \& Quabbaj, N. (2016). Youth employment in start-up ventures in Jordan: an exploratory study. International Journal of Entrepreneurship and Small Business, forthcoming. 
Caputo, A., Mehtap, S., Pellegrini, M. M., \& Al-Refai, R. (2016). Supporting opportunities for female entrepreneurs in Jordan. International Journal of Entrepreneurship and Small Business, 27(2/3), 384-409.

Chau, S. S. (1995). The development of China's private entrepreneurship. Journal of Enterprising Culture, 3(03), 261-276.

Chrisman, J. J., Hynes, T., \& Fraser, S. (1995). Faculty entrepreneurship and economic development: The case of the University of Calgary. Journal of Business Venturing, 10(4). 267-281.

Coviello, N. E. (2006). The network dynamics of international new ventures. Journal of International Business Studies, 37(5): 713-731.

Commander, S., \& Coricelli, F. (Eds.). (1995). Unemployment, restructuring, and the labor market in Eastern Europe and Russia. Washington: World Bank Publications.

Cunningham, J. B., \& Lischeron, J. (1991). Defining entrepreneurship. Journal of Small Business Management, 29(1), 45-61.

Dabić, M. Bašić, M., \& Vlajčić, D. (2013). How entrepreneurial are Croatian counties, Interdisciplinary Studies Journal. 2(4), 24-47.

Dabic, M., Daim, T., Bayraktaroglu, E., Novak, I., \& Basic, M. (2012). Exploring gender differences in attitudes of university students towards entrepreneurship: An international survey. International Journal of Gender and Entrepreneurship, 4(3), 316-336.

Dabic, M., González-Loureiro, M., \& Daim, T. U. (2015). Unravelling the attitudes on entrepreneurial universities: The case of Croatian and Spanish universities. Technology in Society, 42, 167-178.

Dana, L.P. (1997). Change, entrepreneurship and innovation in the Republic of Kazakhstan. Entrepreneurship, Innovation, and Change, 6(2), 167-174.

Dana, L. P. (1998). Waiting for direction in the former Yugoslav Republic of Macedonia (FYROM). Journal of Small Business Management, 36(2), 62-67.

Dana, L. P. (1999). Business and entrepreneurship in Bosnia-Herzegovina. Journal of Business Entrepreneurship, 11(2), 105-117.

Dana, L. P. (2001). Networks, internationalization \& policy. Small Business Economics, 16(2), 57-62.

Dana, L. P. (2001). The education and training of entrepreneurs in Asia. Education+ Training, 43(8/9), 405-416.

Dana, L. P. (2010). When Economies Change Hands: A Survey of Entrepreneurship in the Emerging Markets of Europe from the Balkans to the Baltic States, New York \& Oxford: Routledge.

Dana, L. P., Dana, T. E., \& Spence, M. (2004). Public policy and international expansion of high-technology SMEs: a research agenda. International Journal of Entrepreneurship and Innovation Management, 4(2-3), 116-123.

Dana, L. P., Etemad, H., \& Wright, R. W. (2008). Toward a paradigm of symbiotic entrepreneurship. International Journal of Entrepreneurship and Small Business, 5(2), 109126.

Dana, L.P., Han, M., Ratten, V., \& Velpe I.M. (2012). Toward a theory of internationalization for European entrepreneurship. In: Dana, L., Velpe I.M., Ratten, V., \& 
Han, M. (2012). Handbook of research on European business and entrepreneurship: towards a theory of internationalization (pp. 743-759). Cheltenham: Edward Elgar Publishing.

Dana, L. P., \& Ramadani, V. (2015). Context and Uniqueness of Transition Economies. In Family Businesses in Transition Economies (pp. 39-69). Berlin: Springer International Publishing.

Dandridge, T. C., \& Flynn, D. M. (1988). Entrepreneurship: Forces Which Are Creating Opportunities in China. International Small Business Journal, 9(3), 34-41.

Davidsson, P. (1991). Continued entrepreneurship: Ability, need, and opportunity as determinants of small firm growth. Journal ofBbusiness Venturing, 6(6), 405-429.

De Cleyn, S. H., \& Braet, J. (2009). Research valorisation through spin-off ventures: Integration of existing concepts and typologies. World Review of Entrepreneurship, Management and Sustainable Development, 5(4), 325-352.

Domadenik, P., \& Pastore, F. (2006). Influence of education and training systems on participation of young people in labour market of cee economies: A comparison of Poland and Slovenia. International Journal of Entrepreneurship and Small Business, 3(5), 640-666.

Drucker, P. (2014). Innovation and Entrepreneurship (ed. origin 1985). London: Routledge.

Dutt, N., Hawn, O., Vidal, E., Chatterji, A. K., McGahan, A. M., \& Mitchell, W. (2015). How open system intermediaries address institutional failures: The case of business incubators in emerging-market countries. Academy of Management Journal, 58(6).

FINA (2012), Financial report on Croatian companies, Retrievable at http://www.fina.hr/Default.aspx (Accessed on March 2014).

Elmuti, D., Khoury, G., \& Omran, O. (2012). Does entrepreneurship education have a role in developing entrepreneurial skills and ventures' effectiveness. Journal of Entrepreneurship Education, 15(1), 83-98.

Estrin, S., Hanousek, J., Kočenda, E., \& Svejnar, J. (2009). The effects of privatization and ownership in transition economies. Journal of Economic Literature, 699-728.

Etzkowitz, H. (2004). The evolution of the entrepreneurial university. International Journal of Technology and Globalisation, 1(1), 64-77.

Etzkowitz, H. 2003. Research groups as 'quasi-firms': the invention of the entrepreneurial university. Research Policy, 32(1). 109-121

Etzkowitz, H., and Leydesdorff, L. (2000). The dynamics of innovation: from National Systems and "Mode 2" to a Triple Helix of university-industry-government relations. Research Policy, 29(2), 109-123.

Fayolle, A. (2007). Entrepreneurship and new value creation: the dynamic of the entrepreneurial process. Cambridge: Cambridge University Press.

Fayolle, A. (2008). Entrepreneurship education at a crossroads: Towards a more mature teaching field. Journal of Enterprising Culture, 16(04), 325-337.

Fayolle, A., \& Gailly, B. (2008). From craft to science: Teaching models and learning processes in entrepreneurship education. Journal of European Industrial Training, 32(7), 569-593.

Fayolle, A. (2013). Personal views on the future of entrepreneurship education. Entrepreneurship \& Regional Development, 25(7-8), 692-701. 
Fairlie, R. W. (2013). Entrepreneurship, economic conditions, and the great recession. Journal of Economics \& Management Strategy, 22(2), 207-231.

Feige, E. L., \& Ott, K. (1999). Underground economies in transition: unrecorded activity: tax, corruption and organized crime. Aldershot: Ashgate.

Gaff, B. M., Kimball, R. N., \& Hanson, J. M. (2012). Raising Capital: Where to Find It, How to Secure It, and Tips on What to Avoid. Computer, (7), 11-13.

Glas, M., Drnovšek, M., \& Mirtic, D. (2000). Problems faced by new entrepreneurs: Slovenia and Croatia - a comparison. Paper presented at the 30th European small business seminar, entrepreneurship under difficult circumstances, EFMD, Vlerick Leuven Gent Management School, Gent Belgium, 20-22 September.

Gohmann, S. F. (2012). Institutions, latent entrepreneurship, and Self-Employment: An international comparison. Entrepreneurship Theory and Practice, 36(2), 295-321.

Gorodnichenko, Y., \& Schnitzer, M. (2013). Financial constraints and innovation: Why poor countries don't catch up. Journal of the European Economic Association, 11(5), 11151152.

Greene, P. G., \& Rice, M. P. (2007). Entrepreneurship Education. Cheltenham: Edward Elgar Publishing.

Greenaway, D., Guariglia, A., \& Kneller, R. (2007). Financial factors and exporting decisions. Journal of International Economics, 73(2), 377-395.

Gurau, C. (2002). The internationalization process of UK biopharmaceutical SMEs. Journal of American Academy of Business, 2(1), 241-247.

Gurau, C., \& Dana, L. P. (2010). The evolution of entrepreneurship forms and strategies in transition economies: the case of Romania. International Journal of Entrepreneurship and Small Business, 10(1), 131-147.

He, X. (2009). The development of entrepreneurship and private enterprise in the People's Republic of China and its relevance to transitional economies. Journal of Developmental Entrepreneurship, 14(1), 39-58.

Hessels, J., \& Parker, S. C. (2013). Constraints, internationalization and growth: A crosscountry analysis of European SMEs. Journal of World Business, 48(1), 137-148.

Hisrich, R. D., \& Grachev, M. V. (1993). The Russian entrepreneur. Journal of Business Venturing, 8(6), 487-497.

Hitt, M. A., Dacin, M. T., Levitas, E., Arregle, J.-L., \& Borza, A. (2000). Partner Selection in Emerging and Developed Market Contexts: Resource-based and Organizational Learning Perspectives. Academy of Management Journal, 43(3), 449-467.

Hoxha, D. (2008). Entrepreneurship, employment and fast-growing firms in Kosova. World Review of Entrepreneurship, Management and Sustainable Development, 4(2-3), 203217.

Iakovleva, T., \& Solesvik, M. Z. (2014). Entrepreneurial intentions in post-Soviet economies. International Journal of Entrepreneurship and Small Business, 21(1), 79-100.

Ibicioglu, H., Baysal, H., \& Ozkul, A. S. (2008). The role of high education in entrepreneurship training in respect of transition economies: ALBANIA SAMPLE. In First International Conference on Management and Economics, ICME, March 2008.

Ireland, R. D., \& Webb, J. W. (2006). International entrepreneurship in emerging economies: A resource-based perspective In Cooper. A., Alvarez. S., Carrera, A., Mesquita, 
L., \& Vassolo, R. (eds). Entrepreneurial Strategies: New Technologies and Emerging Markets. (pp.47-70). Malden (MA): Blackwell.

Johannisson, B. (1991). University training for entrepreneurship: Swedish approaches. Entrepreneurship \& Regional Development, 3(1), 67-82.

Johnson S., Kaufmann D., \& Shleifer A. (1997) The unofficial economy in transition. Brookings PapEcon Act, 2, 159-239.

Johnson S., Kaufmann D., McMillan J., \& Woodruff C. (2000) Why do firms hide? Bribes and unofficial activity after communism. Journal of Public Economy, 76, 495-520.

Jones, P., Jones, A., Packham, G., \& Miller, C. (2008). Student attitudes towards enterprise education in Poland: a positive impact. Education + Training,50(7), 597-614.

Joshi, M. (2010). Fostering innovation: transition from chimps to hyena and lion type innovative enterprise. World Review of Entrepreneurship, Management and Sustainable Development, 6(1-2), 2-16.

Julien, P. A. (1989). The entrepreneur and economic theory. International Small Business Journal, 7(3), 29-38.

Kalinic, I., \& Forza, C. (2012). Rapid internationalization of traditional SMEs: Between gradualist models and born globals. International Business Review, 21(4), 694-707.

Kirby, D. A. (2007). Changing the entrepreneurship education paradigm In Fayolle, A. (ed.), Handbook of Research in Entrepreneurship Education (Vol. 1). (pp. 21-45). Chetelham: Edward Elgar Publishing.

Kiss, A. N., \& Danis, W. M. (2010). Social networks and speed of new venture internationalization during institutional transition: A conceptual model. Journal of International Entrepreneurship, 8(3), 273-287.

Klonowski, D. J. (2008). Challenges and opportunities in developing an entrepreneurial business in Poland: the case study of Morawski Printing House. World Review of Entrepreneurship, Management and Sustainable Development, 4(2-3), 261-271.

Knight, F. H. (1921). Risk, uncertainty and profit. New York: Hart, Schaffner and Marx.

Kyläheiko, K., Jantunen, A., Puumalainen, K., Saarenketo, S., \& Tuppura, A. (2011). Innovation and internationalization as growth strategies: The role of technological capabilities and appropriability. International Business Review, 20(5), 508-520.

Laukkanen, M. (2000). Exploring alternative approaches in high-level entrepreneurship education: creating micromechanisms for endogenous regional growth. Entrepreneurship \& Regional Development, 12(1), 25-47.

Lavigne, M. (1995). The economics of transition: from socialist economy to market economy. London: Macmillan.

Lee, S. Y., Florida, R., \& Acs, Z. (2004). Creativity and entrepreneurship: a regional analysis of new firm formation. Regional Studies, 38(8), 879-891.

Lee, S. H., \& Makhija, M. (2009). Flexibility in internationalization: is it valuable during an economic crisis?. Strategic Management Journal, 30(5), 537-555.

Lee, W. O. (2008). The repositioning of high education from its expanded visions: Lifelong learning, entrepreneurship, internationalization and integration. Educational research for policy and practice, 7(2), 73-83. 
Lloyd-Reason, L., Muller, K., \& Wall, S. (2002). Innovation and education policy in SMEs: a Czech perspective. Education + Training, 44(8/9), 378-387.

Manolova, T. S., Manev, I. M., \& Gyoshev, B. S. (2010). In good company: The role of personal and inter-firm networks for new-venture internationalization in a transition economy. Journal of World Business, 45(3), 257-265.

Manolova, T. S., Manev, I. M., \& Gyoshev, B. S. (2014). Friends with money? Owner's financial network and new venture internationalization in a transition economy. International Small Business Journal, 32(8), 944-966.

Marques, L. A., \& Albuquerque, C. (2012). Entrepreneurship education and the development of Young people life competencies and skills. ACRN Journal of Entrepreneurship Perspectives, 1(2), 55-68.

Marshall, A., \& Guillebaud, C. W. (1961). Principles of economics. London: McMillian \& Co.

Matlay, H. (2001). Entrepreneurial and vocational education and training in central and Eastern Europe. Education + Training, 43(8/9), 395-404.

Meager, N. (1992) The fall and rise of self-employment (again): a comment on Bo"genhold and Staber. Work Employment and Society, 6(1), 127-134.

Musteen, M., Francis, J., \& Datta, D. K. (2010). The influence of international networks on internationalization speed and performance: A study of Czech SMEs. Journal of World Business, 45(3), 197-205.

Musteen, M., Datta, D. K., \& Francis, J. (2014a). Early internationalization by firms in transition economies into developed markets: The role of international networks. Global Strategy Journal, 4(3), 221-237.

Musteen, M., Datta, D. K., \& Butts, M. M. (2014b). Do international networks and foreign market knowledge facilitate SME internationalization? Evidence from the Czech Republic. Entrepreneurship Theory and Practice, 38(4), 749-774.

Peng, M. W. (2001). How entrepreneurs create wealth in transition economies. The Academy of Management Executive, 15(1), 95-108.

Petković, S., \& Tešić, J. (2013). SMEs and Entrepreneurship Development and Institutional Support in Republic of Srpska (Bosnia and Herzegovina). In Ramadani, V., \& Schneider, R. C. (2013). Entrepreneurship in the Balkans (pp. 293-315). Berlin: Springer.

Pfeifer, S., Šarlija, N., \& Zekić Sušac, M. (2014). Shaping the Entrepreneurial Mindset: Entrepreneurial Intentions of Business Students in Croatia. Journal of Small Business Management, 54(1), 102-117.

Pollard, D., \& Simberova, I. (2008). On researching the internationalisation of SMEs in transformation economies. World Review of Entrepreneurship, Management and Sustainable Development, 4(2-3), 107-124.

Ramadani, V., \& Dana, L. P. (2013). The state of entrepreneurship in the Balkans: Evidence from selected countries. In Ramadani, V., \& Schneider, R. C. (2013). Entrepreneurship in the Balkans (pp. 217-250). Berlin: Springer.

Ramadani, V. (2013). Entrepreneurship and Small Business in the Republic of Macedonia. Strategic Change, 22(7-8), 485-501. 
Ramadani, V. (2015). The Woman Entrepreneur in Albania: An Exploratory Study on Motivation, Problems and Success Factors. Journal of Balkan and Near Eastern Studies, 17(2), 204-221.

Ramadani, V., Hisrich, R.D. \& Gerguri-Rashiti S. (2015). Female Entrepreneurs in Transition Economies: Insights from Albania, Macedonia and Kosovo. World Review of Entrepreneurship, Management and Sustainable Development, 11(4), 391-413.

Ratten, V. (2014). Encouraging collaborative entrepreneurship in developing countries: the current challenges and a research agenda. Journal of Entrepreneurship in Emerging Economies, 6(3), 298-308.

Schumpeter, J. A. (1942). Capitalism, socialism and democracy. London: Routledge.

Shane, S., \& Venkataraman, S. (2000). The promise of entrepreneurship as a field of research. Academy of management review, 25(1), 217-226.

Shepherd, D.A. (2003). Learning from business failure: Propositions of grief recovery for the self-employed. Academy of Management Review, 28(2), 318-328.

Slaughter, S., \& Leslie, L. L. (1997). Academic capitalism: Politics, policies, and the entrepreneurial university. Baltimore (MD): The Johns Hopkins University Press.

Smallbone, D., \& Welter, F. (2001). The distinctiveness of entrepreneurship in transition economies. Small Business Economics, 16(4), 249-262.

Smallbone, D., \& Welter, F. (2006). Conceptualising entrepreneurship in a transition context. International Journal of Entrepreneurship and Small Business, 3(2), 190-206.

Sohinger, J., \& Horvatin, D. (2005). Foreign direct investment and competitiveness in transition economies: the case of Croatia. International Journal of Entrepreneurship and Small Business, 2(3), 266-282.

Sporn, B. (2001). Building Adaptive Universities: Emerging Organisational Forms Based on Experiences of European and US Universities. Tertiary Education and Management, 7(2). 121-134.

Swank, D. (2006). Tax policy in an era of internationalization: explaining the spread of neoliberalism. International Organization, 60(04), 847-882.

Tang, Y-K. (2011). The influence of networking on the internationalization of SMEs: Evidence from internationalized Chinese firms. International Small Business Journal, 29(4), 374-398.

Tipu, S. A. A. (2012). What have we learned? Themes from the literature on necessity driven entrepreneurship. World review of entrepreneurship, management and sustainable development, 8(1), 70-91.

Thomson, J. L. (2004). The facets of the entrepreneur: Identifying entrepreneurial potential. Management Decision, 42(2), 243-258.

Tridico, P. (2013). Values, institutions and models of institutional change in transition economies after the fall of Berlin Wall. Challenge, 56(3), 6-27.

Van der Kuip, I., \& Verheul, I. (2004). Early development of entrepreneurial qualities: the role of initial education. Journal of Entrepreneurship Education, 2(2).

Varblane, U., \& Mets, T. (2010). Entrepreneurship education in the higher education institutions (HEIs) of post-communist European countries. Journal of Enterprising Communities: People and Places in the Global Economy, 4(3), 204-219. 
Venkataraman, S. (2004). Regional transformation through technological entrepreneurship. Journal of Business Venturing, 19(1), 153-167.

Welter, F. (2011). Contextualizing Entrepreneurship-Conceptual Challenges and Ways Forward. Entrepreneurship Theory and Practice, 35(1), 165-184.

Westhead, P., Wright, M., \& Ucbasaran, D. (2001). The internationalization of new and small firms: A resource-based view. Journal of Business Venturing, 16(4), 333-358.

Williams, C. C. (2011). Entrepreneurship, the informal economy and rural communities. Journal of Enterprising Communities: People and Places in the Global Economy, 5(2), 145157.

Williams, C. C. (2015). Tackling informal employment in developing and transition economies: a critical evaluation of the neo-liberal approach. International Journal of Business and Globalisation, 14(3), 251-270.

Wilton, W., and Toh, W. (2012). Determinants of entrepreneurship: a framework for successful entrepreneurship. World Review of Entrepreneurship, Management and Sustainable Development, 8(3), 285-296.

Wong, P. K., Ho, Y. P., \& Autio, E. (2005). Entrepreneurship, innovation and economic growth: Evidence from GEM data. Small Business Economics, 24(3), 335-350.

Wolf, B. M. (1977). Industrial diversification and internationalization: Some empirical evidence. The Journal of Industrial Economics, 177-191.

Wright, R. W., and Dana, L-P. (2003). Changing Paradigms of International Entrepreneurship Strategy. Journal of International Entrepreneurship 1 (1), 135-152.

Wright, M., \& Stigliani, I. (2013). Entrepreneurship and growth. International Small Business Journal, 31(1), 3-22.

Young, S., Dimitratos, P., \& Dana, L. P. (2003). International entrepreneurship research: what scope for international business theories?. Journal of International Entrepreneurship, $1(1), 31-42$.

Zahra, S. A. (2005). Toward a theory of international new ventures: Reflections on a decade of research. Journal of International Business Studies, 36, 29-41.

Zapalska, A. (1997). Profiles of Polish entrepreneurship. Journal of Small Business Management, 35(2), 111-117.

Zucchella, A., Palamara, G., \& Denicolai, S. (2007). The drivers of the early internationalization of the firm. Journal of World Business, 42(3), 268-280. 


\section{List of Figure}

Figure 1 Traditional Network-based approach to internationalisation

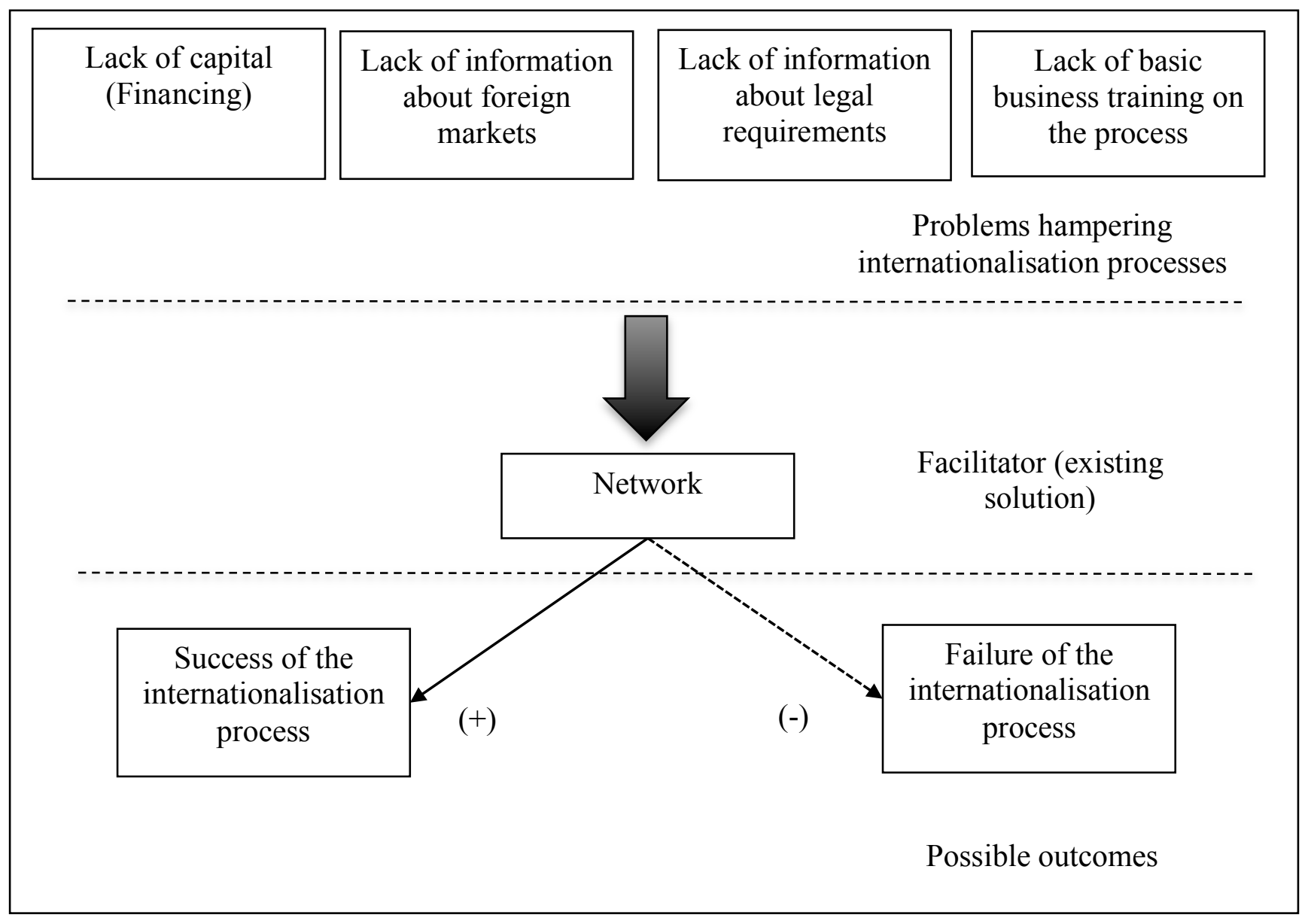


Figure 2 Integrated approach to internationalisation

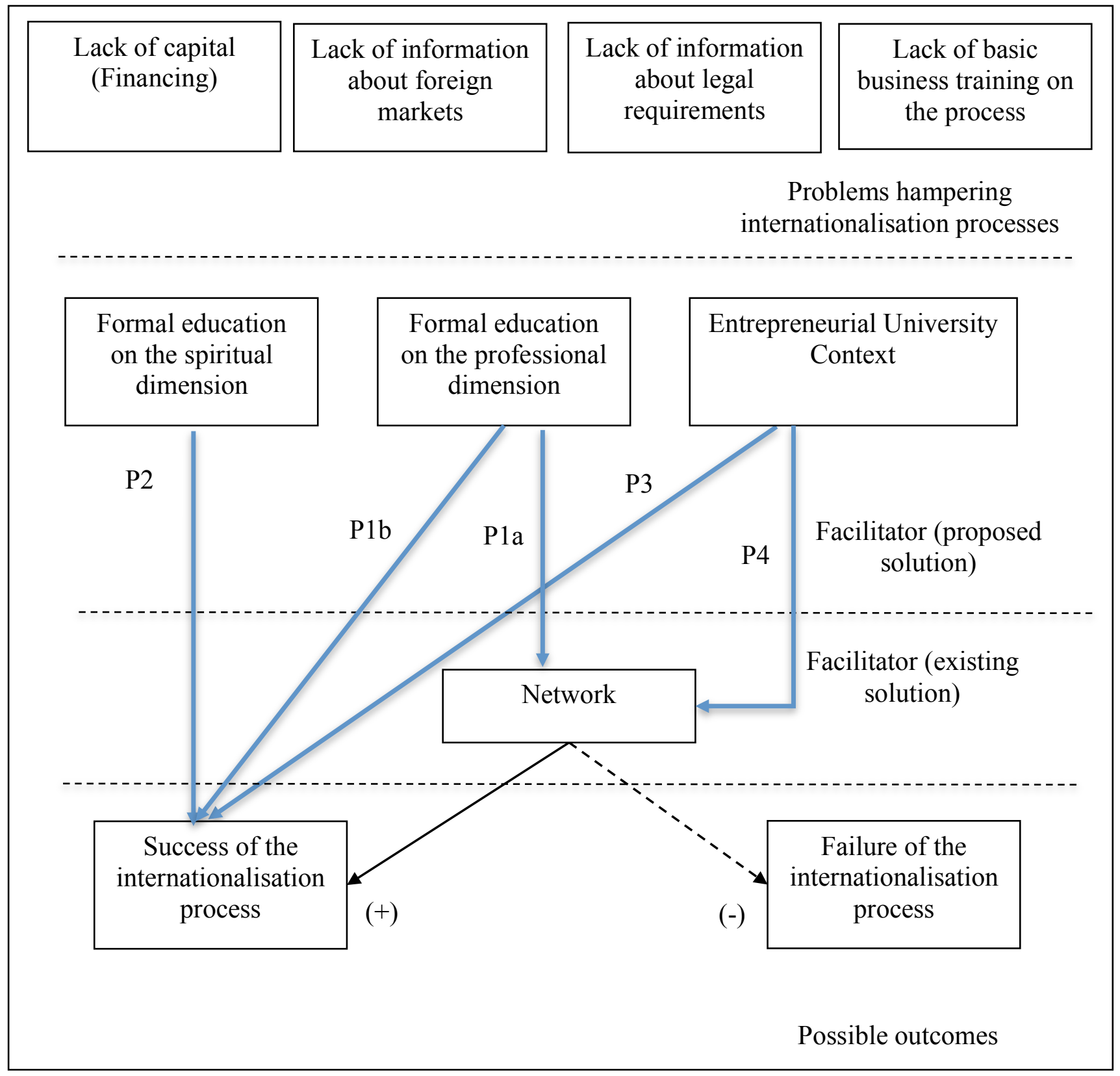

